\title{
Correction to: Publication of Decision Model Source Code: Attitudes of Health Economics Authors
}

\author{
Joanna Emerson ${ }^{1} \cdot$ Rachel Bacon $^{1} \cdot$ Alma Kent $^{1} \cdot$ Peter J. Neumann ${ }^{1} \cdot$ Joshua T. Cohen $^{1}$
}

Published online: 19 June 2019

(c) The Author(s) 2019

\section{Correction to: PharmacoEconomics https://doi.org/10.1007/s40273-019-00796-3}

The article Publication of Decision Model Source Code: Attitudes of Health Economics Authors written by Joanna Emerson, Rachel Bacon, Alma Kent, Peter J. Neumann, Joshua T. Cohen was originally published electronically on the publisher's internet portal (currently Springerlink) on May 8, 2019 without open access.

With the author(s)' decision to opt for Open Choice the copyright of the article changed on June 2019 to $($ ) The Author(s) (2019) and the article is forthwith distributed under the terms of copyright.

The original article was corrected.
The original article can be found online at https://doi.org/10.1007/ s40273-019-00796-3.

Joshua T. Cohen

jcohen@tuftsmedicalcenter.org

1 Center for the Evaluation of Value and Risk in Health, Institute for Clinical Research and Health Policy Studies, Tufts Medical Center, Boston, MA 02111, USA
Open Access This article is distributed under the terms of the Creative Commons Attribution 4.0 International License (http://creativeco mmons.org/licenses/by/4.0/), which permits unrestricted use, distribution, and reproduction in any medium, provided you give appropriate credit to the original author(s) and the source, provide a link to the Creative Commons license, and indicate if changes were made. 